\title{
KUNTOUTUKSEN UUDISTAMISKOMITEAN EHDOTUSTEN TOIMEENPANO
}

\section{PÄÄKIRJOITUS}

ERJA POUTIAINEN
Vuonna 2017 Kuntoutuksen uudistamiskomitea jätti raporttinsa, jossa esitti yhteensä 55 ehdotusta kuntoutusjärjestelmän uudistamiseksi. Pitkään näytti siltä, että ehdotusten toimeenpano ei juuri edennyt, sote-uudistus polki paikallaan ja maan hallituskin vaihtui. Nyt pääministeri Sanna Marinin hallitusohjelman linjausten mukaisesti kuntoutusta on kuitenkin ryhdytty aktiivisesti kehittämään kuntoutuskomitean työn pohjalta.

Kuntoutuksen tietopohjan vahvistaminen oli yksi kuntoutuksen uudistamiskomitean esittämä kehittämiskohde. Sitä lähdettiin edistämään jo vuoden 2019 keväällä Kuntoutuksen tietopohja (Kuti) -hankkeen puitteissa. Terveyden ja hyvinvoinnin laitos (THL) sai tehtäväkseen koota asiantuntijatyöryhmiä laatimaan suosituksia yleisesti saatavilla olevista ja kaikille sote-toimijoille yhteiseen käyttöön soveltuvista toimintakyvyn ja kuntoutustarpeen karkean arvioinnin menetelmistä sekä siitä, missä hoito- ja kuntoutuspolun vaiheessa kyseisiä menetelmiä olisi tarkoituksenmukaista käyttää. Tähän työhön perustettiin kaksi erillistä asiantuntijatyöryhmää. Näistä toisen tehtävänä oli tunnistaa aikuisten toimintakyvyn itsearviointiin kuntoutumistarpeen tunnistamisessa ja kuntoutumisen seurannassa soveltuvia arviointimenetelmiä ja toisen aivoverenkiertohäiriön (AVH) sairastaneiden toimintakyvyn vähimmäisarviointiin kuntoutustarpeen arvioinnissa ja kuntoutuspalveluissa soveltuvia menetelmiä. Suositukset on nyt julkaistu, ja ne löytyvät THL:n sivuilta (https://thl. fi/fi/tutkimus-ja-kehittaminen/tutkimukset-ja-hankkeet/kuntoutuksen-tietopohja-hanke-kuti-/suositukset-ja-materiaalit).

Kuti-hankkeen suositukset ovat askel kohti sote-ammattilaisille yhteisten menetelmien käyttöönottoa. Tavoitteena on, että vertailtavuus eri toimijoiden välillä paranee ja yksilön toimintakyvyn ajallisen muutoksen seuranta helpottuu. Suositeltujen arviointimenetelmien toimivuutta ja soveltuvuutta samoin kuin niissä ehdotettuja arviointiajankohtia tulee kuitenkin tarkastella jatkossa kriittisesti esimerkiksi erilaisten systemaattisten kokeilujen ja tutkimuksellisen tiedonkeruun avulla.

On myös tärkeää huomioida, että suosituksissa ehdotetut arviointimenetelmät on tarkoitettu karkeaan vähimmäisarviointiin. Hyvin usein kuntoutustarpeen selvittämiseen tarvitaan lisäksi erityisosaamista edellyttäviä tarkempia arviointeja, eikä niiden merkitys ole näiden suositusten myötä vähentynyt. 
Tämän vuoden alusta sosiaali- ja terveysministeriö on uuden kuntoutuskoordinaattorin tehtävän myötä ryhtynyt aktiivisesti edistämään kuntoutuskomitean ehdotusten täytäntöönpanoa. Yhdessä ministeriöiden ja kuntoutusalan toimijoiden kanssa on kevään aikana pidetty ministeri Krista Kiurun pyöreän pöydän tilaisuus, siihen liittyvä jatkotilaisuus, ikäryhmäkohtaisesti kuntoutusta käsitteleviä työpajoja ja sidosryhmien kuulemisia. Näiden tapaamisten ja kuulemisten antia pyritään hyödyntämään kuntoutuksen tiekartan laadinnassa. Kuntoutuksen uudistamistyö on tarkoitus sitoa osaksi erilaisten toimintamallien toimeenpanoja, kuten esimerkiksi tulevaisuuden sote-keskusohjelmaa, työkykyohjelmaa tai mielenterveysstrategian toimeenpanoa. Kuntoutuksen uudistamiskomitean suositusten mukaisesti pureudutaan Kuti-hankkeen myötä jo aloitetun sote-tietopohjan ja järjestelmien kehittämisen lisäksi myös valtakunnallisiin kuntoutuksen pääsyn periaatteisiin sekä kuntoutusalan koulutukseen, tutkimukseen ja osaamiseen.

Kuntoutuksen tiekartan on tarkoitus valmistua alkusyksystä 2020. On ollut ilahduttavaa huomata, että monet eri kuntoutusalan yhteenliittymät ovat omilla tahoillaan lähteneet edistämään kuntoutuksen tiekartan jäsentymistä ja sen myötä kuntoutuksen uudistamistyötä. Näyttää siltä, että tulevasta syksystä on tulossa kuntoutuksen kehittämisen kannalta hyvin kiinnostava ajanjakso.

Tämän eriskummallisen koronakevään jälkeen kuntoutuksen tarve todennäköisesti korostuu entisestään. Myös tämä huomioon ottaen on tärkeää, että kuntoutusta jatkuvasti kehitetään ja uudistetaan ajan vaatimusten mukaisesti.

Kuntoutus-lehti pyrkii osaltaan pitämään huolta kuntoutuksen osaamisesta ja sen päivittymisestä julkaisemalla jokaisessa numerossa laajasti kuntoutusalaa kiinnostavia kirjoituksia. Tässä lehdessä kuvataan erilaisia kuntoutuksen toteutusmuotoja samoin kuin eri kohderyhmille suunnattua kuntoutusta ja näiden kokemuksia saamastaan tuesta. Useissa tämän numeron kirjoituksissa näkökulmana on kuntoutuksen ja toimijuuden tuen sosiaalinen ulottuvuus.

Toivotan lukijoille oikein rentouttavaa kesäaikaa!

Erja Poutiainen

päätoimittaja

Kuntoutussäätiö 